\title{
Review
}

\section{The Role of Wild-Type RAS in Oncogenic RAS Transformation}

\author{
Erin Sheffels (1) and Robert L. Kortum* \\ Department of Pharmacology and Molecular Therapeutics, Uniformed Services University of the Health Sciences, \\ Bethesda, MD 20814, USA; erin.sheffels@gmail.com \\ * Correspondence: robert.kortum@usuhs.edu
}

check for

updates

Citation: Sheffels, E.; Kortum, R.L. The Role of Wild-Type RAS in Oncogenic RAS Transformation. Genes 2021, 12, 662. https://doi.org/ 10.3390 /genes12050662

Academic Editor:

Esther Castellano-Sánchez

Received: 9 April 2021

Accepted: 27 April 2021

Published: 28 April 2021

Publisher's Note: MDPI stays neutral with regard to jurisdictional claims in published maps and institutional affiliations.

Copyright: (c) 2021 by the authors. Licensee MDPI, Basel, Switzerland. This article is an open access article distributed under the terms and conditions of the Creative Commons Attribution (CC BY) license (https:/ / creativecommons.org/licenses/by/ $4.0 /)$.

\begin{abstract}
The RAS family of oncogenes (HRAS, NRAS, and KRAS) are among the most frequently mutated protein families in cancers. $R A S$-mutated tumors were originally thought to proliferate independently of upstream signaling inputs, but we now know that non-mutated wild-type (WT) RAS proteins play an important role in modulating downstream effector signaling and driving therapeutic resistance in RAS-mutated cancers. This modulation is complex as different WT RAS family members have opposing functions. The protein product of the WT RAS allele of the same isoform as mutated RAS is often tumor-suppressive and lost during tumor progression. In contrast, RTK-dependent activation of the WT RAS proteins from the two non-mutated WT RAS family members is tumor-promoting. Further, rebound activation of RTK-WT RAS signaling underlies therapeutic resistance to targeted therapeutics in RAS-mutated cancers. The contributions of WT RAS to proliferation and transformation in $R A S$-mutated cancer cells places renewed interest in upstream signaling molecules, including the phosphatase/adaptor SHP2 and the RasGEFs SOS1 and SOS2, as potential therapeutic targets in RAS-mutated cancers.
\end{abstract}

Keywords: RAS; KRAS; HRAS; NRAS; SOS1; SOS2; RTK; SHP2; resistance

\section{Introduction}

The RTK/RAS pathway (Figure 1A) is among the most commonly mutated pathways in cancer [1,2]. The three $R A S$ genes, $H R A S, N R A S$, and $K R A S$, encode four highly homologous protein isoforms (HRAS, NRAS, KRAS4A, and KRAS4B), driver mutations in RAS genes occur in $\sim 20 \%$ of human tumors (reviewed in [3]). KRAS is the most frequently mutated RAS family member (75\% of RAS mutations), including high incidence of mutations in lung [4], colon [5], and pancreatic cancers [6], three of the top four causes of cancer-related death $[2,7,8]$. HRAS and NRAS mutations are common in other cancer types including head and neck, skin, and hematopoietic cancers [9]. RAS-mutated cancers respond poorly to standard chemotherapy [10-14], so targeted approaches are needed to treat patients with $R A S$-mutated tumors. While advances in targeting specific mutant RAS proteins have been made [15-18], the majority of $R A S$-mutated tumors remain resistant to currently available treatments $[4,12,14,19,20]$. Novel strategies for targeting the RAS pathway are necessary to provide effective therapeutics to the majority of patients with $R A S$-mutated cancers. Understanding the signaling context of mutant RAS is key to developing indirect targeting and combination therapy strategies to better manage these cancers.

While typical models of oncogene activation assume that the mutated protein drives oncogenesis separately from the wild-type family members, the evidence that non-mutant wild-type (WT) RAS proteins influence cancer initiation and growth in $R A S$-mutated cancers is now well-established and several mechanisms for the effects have been proposed. Here, we summarize the current understanding of the effects of WT RAS on RAS-mutated cancers and the proposed mechanisms behind those effects. 


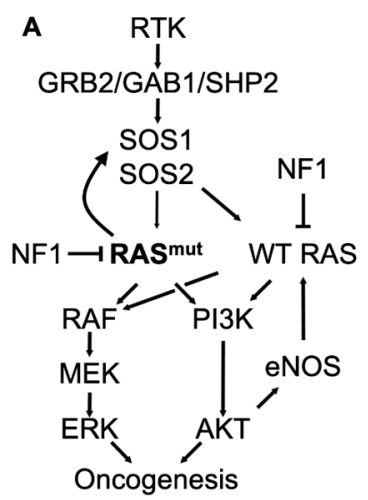

B

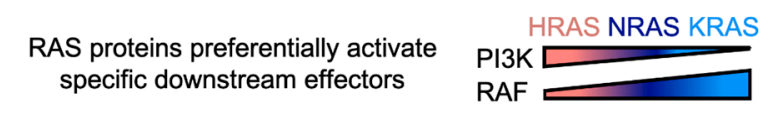

c

\begin{tabular}{|ccc|ccc|}
\multicolumn{3}{c}{ HRAS-mutated cell } & \multicolumn{3}{c}{ KRAS-mutated cell } \\
\hline mutant & WT & WT NRAS & mutant & WT & WT HRAS \\
HRAS & - HRAS & WT KRAS & KRAS & KRAS & WT NRAS \\
1 & T & $\downarrow$ & $\downarrow$ & T & $\downarrow$ \\
PI3K & $(L O H)$ & RAF & MEK \\
AKT & $(L O H$ & RAF & $(L O H)$ & PI3K \\
& & ERK & & AKT \\
& & ERK & & \\
\hline
\end{tabular}

Figure 1. Mutant RAS and WT RAS cooperate to promote oncogenesis. (A) Schematic showing mutant RAS and WT RAS signaling in RAS-mutated cancer cells. (B) RAS family members show differential activation of downstream RAS effectors. HRAS activates PI3K well but RAF relatively poorly; KRAS activates RAF well but PI3K poorly. (C) Schematic showing proposed activation of RAF/MEK/ERK versus PI3K/AKT signaling in HRAS- and KRAS-mutated cancer cells. In HRASmutated cells, mutant HRAS activates PI3K/AKT signaling, whereas RTK-WT N/KRAS activate RAF/MEK/ERK signaling. WT HRAS is tumor suppressive and inhibits mutant HRAS signaling. In KRAS-mutated cells, mutant KRAS activates RAF/MEK/ERK signaling, whereas RTK-WT H/NRAS activate PI3K/AKT signaling. WT KRAS is tumor suppressive and inhibits mutant KRAS signaling.

\section{Contributions of WT RAS to Mutant RAS-Driven Cancers}

Non-mutant WT RAS proteins play an important role in modulating downstream effector signaling and oncogenesis in RAS-mutated cancers. While the contributions of WT RAS to RAS-mutated cancers varies based on factors such as the specific RAS isoform that is mutated and the cancer type, WT RAS proteins can be broadly categorized into two groups with opposing biologic functions. The protein product of the WT RAS allele of the same isoform as mutated RAS is tumor-suppressive, whereas the WT RAS proteins from the two non-mutated WT RAS family members are tumor-promoting (Figure 1B and reviewed in [21]).

\subsection{The WT RAS Allele of the Same Isoform as Mutated RAS Inhibits Tumorigenesis}

Several studies have found that the WT allele corresponding to the specific mutated RAS gene (WT HRAS in HRAS-mutated cancers [22,23]; WT NRAS in NRAS-mutated cancers [24,25]; WT KRAS in KRAS-mutated cancers [23,26-30]) suppresses tumorigenesis. Further, many $R A S$-mutated cancers have loss of heterozygosity $(\mathrm{LOH})$ at the mutated gene, suggesting that loss of the wild-type allele confers a growth advantage. Evidence for $\mathrm{LOH}$ as a frequent event in cancer initiation has been observed in model systems for all three RAS genes (HRAS [23,31-34], NRAS [21,24,35], KRAS [21,36-39]). A survey of human tumor samples, cancer cell lines, and xenografts of lung, pancreatic, and colorectal cancers found mutant allele specific imbalance (MASI), where the mutant allele makes up more than half of the gene copies, in 58\% of KRAS-mutated samples; over half of these imbalances were due to complete loss of the wild-type allele (uniparental disomy) [40]. Other surveys of both KRAS-mutated [41,42] and HRAS-mutated [43] patient tumor samples have found similar results. KRAS MASI is associated with worse prognosis in colorectal cancer and pancreatic cancer [44] and loss of the WT KRAS allele has been found at a higher rate in metastatic $K R A S$-mutated lung and pancreatic cancers compared to the primary tumors [36,37]. Several mechanisms have been proposed for inhibition of mutant RAS by the corresponding wild-type RAS. MASI and concomitant loss of the wild-type allele would increase the dosage of the mutant allele, increasing the number of mutant RAS proteins signaling in the cell, potentially increasing the oncogenic growth signal. Increased copy number of KRAS has been correlated with increased cell fitness in AML and CRC cells [41] and more aggressive and undifferentiated states in metastatic murine PDAC cells [45]. In patients, KRAS mutations combined with copy number gains were associated 
with decreased survival in lung cancer compared to KRAS mutations without copy number gains ( $\mathrm{LOH}$ due to uniparental disomy or no $\mathrm{LOH}$ ) [40].

Increased dosage of the mutant allele due to MASI does not, however, fully account for the effects of WT RAS of the same isoform; the level of WT KRAS also plays an important role in determining the extent of mutant KRAS-driven tumorigenesis. To examine the effects of WT KRAS levels on mutant KRAS-driven tumorigenesis, To et al. [27] crossed the Kras $2^{2 A 2}$ lung cancer model into different mouse strains that show differing amounts of expression from the endogenous WT Kras allele. They found an inverse correlation between WT KRAS expression and tumorgenesis; mouse strains with lower relative expression of the WT Kras allele showed enhanced tumorigenicity. These data indicated that changes in copy number of the mutant KRAS allele do not fully explain the impact of WT KRAS on inhibiting tumorigenesis. To further probe the effects of WT KRAS on mutant KRASdriven tumorigenesis, Ambrogio et al. [29] used both mice and RASless MEFs containing floxed WT Kras, and found that removal of WT KRAS enhanced mutant KRAS-driven signaling, proliferation, and tumorigenesis. Mechanistically, they found that the ability of WT KRAS to heterodimerize with mutant KRAS was necessary for its inhibitory function, as a dimerization deficient WT KRAS construct was unable to inhibit tumorigenesis. In contrast, they found that homodimers of mutant KRAS were essential for KRAS oncogenic function. These data corroborated findings that mutant KRAS may act as a dimer, requiring both monomers to be activated to achieve full downstream effector engagement [46,47]. In a cell with both constitutively active mutant KRAS and regulated WT KRAS, only dimers composed of two mutant KRAS proteins would provide a full oncogenic signal. Loss of WT KRAS, either through MASI or decreased expression of the wild-type allele, would increase the fraction of dimers composed of two mutants, increasing the oncogenic signal output. In addition to KRAS, both HRAS and NRAS have all been reported to dimerize [29,46-49], but the biologic effects of RAS dimerization and whether a similar mechanism underlies the tumor suppressive functions of WT HRAS and NRAS are untested. Of the three RAS family members, inhibition of mutant KRAS by WT KRAS is the most consistently observed across cancer types. KRAS dimerization may be the primary contributor, although changes in dosage of the mutant protein due to loss of the wild-type allele likely also impact the oncogenic signal. In cancers with copies of the wild-type allele remaining, the inhibition of mutant RAS by the corresponding wild-type RAS isoform indicates that therapies that specifically target the oncogenic mutant may perform better than therapies that target the mutant and wild-type proteins [36].

\subsection{WT RAS Family Members Distinct from the Mutated RAS Allele Promote Oncogenesis}

While WT RAS of the same isoform generally inhibits tumor initiation and growth, the protein products of the two non-mutated, WT RAS genes (for example HRAS and NRAS in a KRAS-mutated cancer; hereafter called WT RAS in all cases) are tumor promoting in RAS-mutated tumors [30,50]. Deletion of WT HRAS lead to decreased proliferation and increased apoptosis in KRAS-mutated endometrial cancer cells [30]. Knockdown of both WT RAS family members decreased proliferation in cell lines with mutated HRAS (T24), NRAS (RD), and KRAS (Mia PaCa 2) [50]. Mechanistically, knockdown of either the mutated RAS isoform or WT RAS differentially altered basal versus RTK-stimulated effector pathway activation [50]. Similar to signaling effects seen with oncogene-targeted inhibitors (see Section 4), these two signals cross-regulated each other: knockdown of either mutated RAS or WT RAS enhanced signaling through the other RAS pathway and simultaneous inhibition of both mutant RAS and WT RAS were required to promote apoptosis [50].

In in vivo models, deletion of individual WT Ras has shown variable effects on mutant RAS-driven tumorigenesis. In skin, WT Kras deletion promoted the progression of Hras-mutated papillomas to invasive squamous carcinomas, whereas WT Nras deletion decreased the formation of Hras-mutated papillomas [23]. Further, WT Nras deletion enhanced whereas WT Hras deletion inhibited Kras-mutated lung carcinogenesis [23]. In KRAS-mutated endometrial cancer cells, individual deletion of WT HRAS or NRAS limited 
proliferation in cancer cells, but not xenograft tumor growth [30]. These data suggest that the roles of WT RAS isoforms are complex and dependent on specific cellular context. To broadly examine the effects of WT RAS deletion in KRAS-mutated cancer cells, we performed a meta-analysis of mutated KRAS, WT HRAS, and WT NRAS dependencies in $K R A S$-mutated colorectal cancer, non-small cell lung cancer, and pancreatic cancer cell lines from both the Dependency Map Portal (DepMap) [51-53] and a large-scale siRNA knockdown screen that assessed RNAi depletion of RAS pathway 'nodes' (siRNEN Screen [54]). Analysis of both combined RNAi (Figure 2A) and AVANA/CRISPR screens (Figure 2B) showed a significant growth disadvantage in cells with mutant KRAS knockdown or deletion, but not in cells where WT HRAS or NRAS were individually removed. In contrast to DepMap data, which analyzed individual gene knockdowns, the siREN screen knocked down all genes of genetic 'nodes' simultaneously; thus the WT RAS node knocked down both HRAS and NRAS. In both colorectal cancer and pancreatic cancer cells, simultaneous knockdown of WT HRAS + NRAS limited survival to a similar extent as knockdown of mutated KRAS did (Figure 2C). Further, there was a direct correlation between individual cell line's sensitivities to knockdown of mutated $K R A S$ and $\mathrm{WT}(H+N) R A S$, suggesting that mutant KRAS and WT $(H+N) R A S$ act together to drive proliferation in these cells [54] (Figure 2D). Interestingly, the lung adenocarcinoma cells did not show dependency to either mutated KRAS or WT RAS in siREN screen data. This observation reflects previous observations that KRAS-mutated lung adenocarcinoma cells are "KRAS-independent" in 2D culture [55-59], but still require KRAS for anchorage-independent growth [60-63], and some KRAS ${ }^{G 12 C}$-mutated NSCLC cell lines respond to KRAS ${ }^{G 12 C}$ inhibitors in 3D culture and in vivo but not in 2D adherent culture [16]. Overall, these data highlight the importance of WT RAS signaling to promote tumorigenesis in $R A S$-mutated cancers.

A
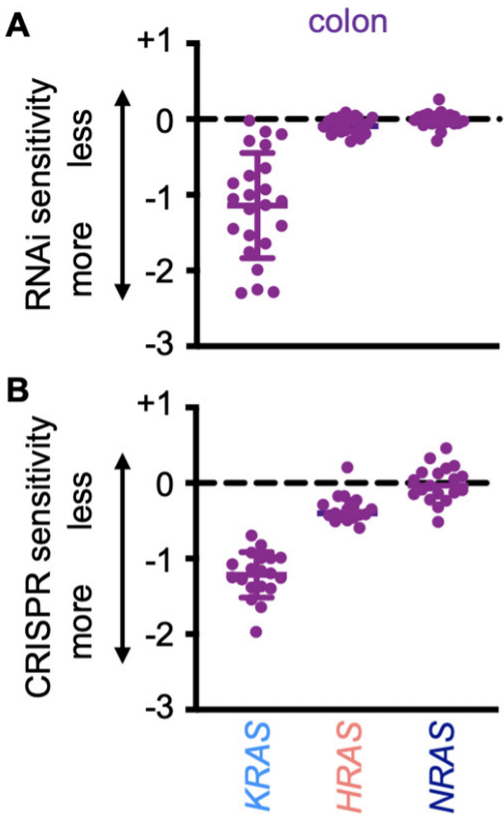

DemMap Portal
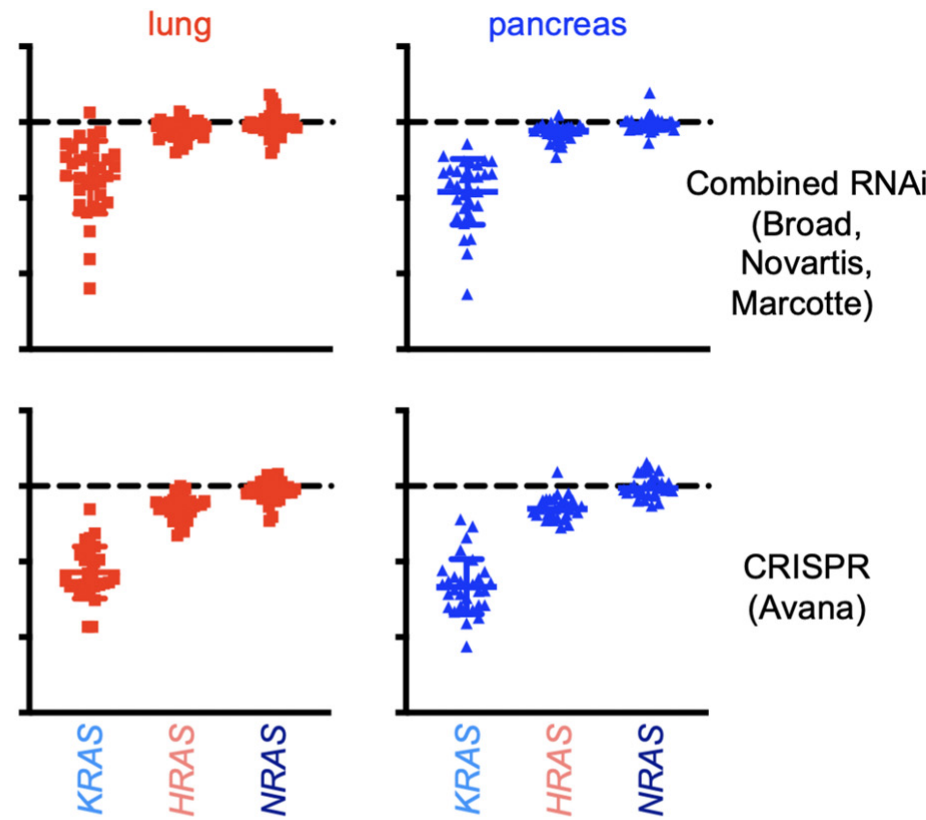

CRISPR

(Avana)

Figure 1. Cont. 
C

siREN Screen (Yuan et al, 2018)
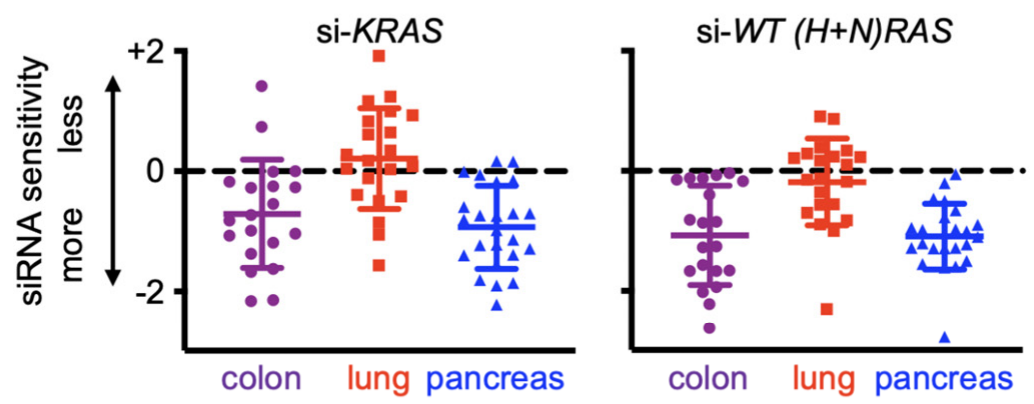

SiREN

RNAi
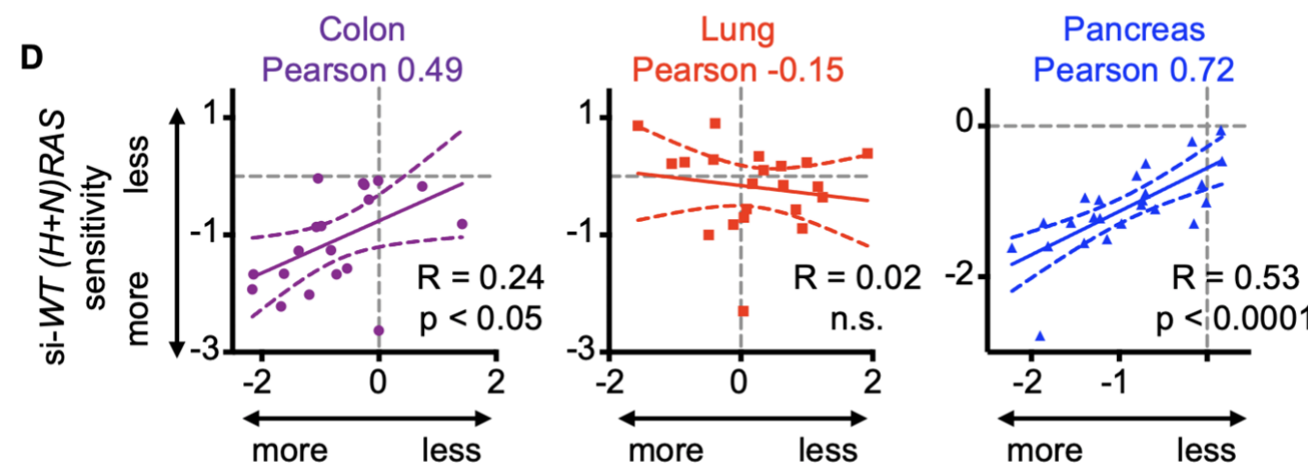

SiREN

RNAi

si-KRAS sensitivity

si-KRAS sensitivity

si-KRAS sensitivity

Figure 2. WT HRAS+NRAS knockdown correlates with mutant KRAS knockdown in KRAS-mutated colorectal and pancreatic cancer cell lines. (A,B) Gene effect of combined RNAi knockdown (Broad, Novartis, Marcotte, A) or CRISPRmediated deletion (Avana, B) of KRAS, HRAS, or NRAS from the DepMap Portal data set in KRAS-mutated colorectal, NSCLC, and pancreatic cancer cell lines. (C,D) Effect of siRNA knockdown of mutant KRAS or both non-mutated WT RAS (HRAS and NRAS) genes (C) or linear correlation between mutant KRAS and WT RAS knockdown (D) from the siREN screen [23] in KRAS-mutated colorectal, NSCLC, and pancreatic cancer cell lines. Pearson correlation coefficient is shown. Each symbol indicates an individual cell line.

\section{Mechanisms of WT RAS Activation in RAS-Mutated Cancers}

Multiple mechanisms have been proposed to describe the activation of WT RAS in the context of mutant RAS. Broadly, WT RAS activation has been described as either mutant RAS-dependent or RTK-dependent, although these two mechanisms are likely interdependent and act in concert to fully activate WT RAS.

\subsection{Mutant RAS-Dependent and RTK-Dependent Mechanisms Activate WT RAS in RAS-Mutated Tumor Cells}

The Kuriyan and Bar Sagi groups identified an allosteric RAS-GTP binding pocket on SOS1 that is distinct from the catalytic SOS1 domain [64]. RAS-GTP binding to this allosteric pocket relieves SOS1 autoinhibition $[65,66]$, increasing SOS1 catalytic activity 80- to 500-fold [64] and activating a RAS-GTP-SOS1-WT RAS positive feedback that has been proposed to allow for 'switch-like' digital RAS activation [67-69]. This 'switch-like' behavior is important for normal childhood development [70,71], T and B cell development [72-74] and activation [75,76], and mutant KRAS-dependent cell proliferation and oncogenesis [77]. While SOS2 contains a homologous allosteric RAS-GTP binding site, whether SOS2 can be allosterically activated remains unconfirmed.

Independent of mutant RAS, RTK-dependent activation of WT RAS promotes activation of downstream effectors in parallel with constitutive mutant RAS signaling [50]. Knockdown studies showed that the non-mutated WT RAS genes are necessary for growthfactor-mediated signaling to RAS effector pathways in HRAS-, NRAS, and KRAS-mutated cancer cells $[30,50]$, indicating that cancer cell response to growth factors may be mediated 
by WT RAS, not the oncogenic RAS mutant. RTK-WT RAS signaling supplements basal mutant RAS signaling to fully activate RAF/MEK/ERK and PI3K/AKT effector pathways [50,78] to promote proliferation [50] and G2 checkpoint integrity [79] in RAS-mutated cancer cells. Intriguingly, the McCormick lab showed that mutant RAS and WT RAS signals cross-regulate each other; knockdown of mutated RAS enhances RTK-WT RAS signaling to downstream effectors and conversely knockdown of WT RAS enhances basal RAS effector activation [50]. Due to this cross-regulation, which is likely due to rebound signaling (see Section 4), they further showed that combined inhibition of both mutant RAS and WT RAS signaling was necessary to induce apoptosis in RAS-mutated cancer cells.

These two mechanisms of WT RAS activation are not mutually exclusive and likely cooperate in some contexts. For example, positive feedback activation of SOS1 by active RAS-GTP potentiates EGF signaling to downstream effectors in vitro [66] and supports prolonged RAS and ERK activation downstream of T cell and B cell receptors [75,76]. Further, other signaling mechanisms can contribute to WT RAS activation in a contextspecific manner. For example, endothelial nitric oxide synthase (eNOS) is phosphorylated and activated by RAS-AKT signaling; eNOS can in turn nitrosylate and activate WT HRAS generating a positive feedback loop that contributes to cellular transformation and tumor maintenance [80].

\subsection{The RasGEFs SOS1 and SOS2 May Play Non-Overlapping Roles in Cells Expressing Oncogenic RAS}

Data from our lab and others suggests that SOS1 and SOS2 may play non-overlapping roles in RAS-mutated tumors. Mutant KRAS-SOS1-WT RAS allosteric signaling promotes growth of KRAS-mutated pancreatic cancer cell xenografts [77], but has not been assessed for mutant HRAS- or NRAS-dependent transformation. In contrast, we found that RTK-SOS2-WT RAS signaling, but not allosteric SOS2 activation, is a critical mediator of mutant KRAS-driven transformation [81] by protecting KRAS-mutated cancer cells from anoikis [82]. We further showed that there was a hierarchical requirement for SOS2 to drive mutant RAS-dependent transformation, with KRAS > NRAS > HRAS. These data suggest that signaling via SOS1 and SOS2 may promote unique aspects of WT RAS signaling in RAS-mutated tumors.

\subsection{WT RAS Cooperates with Mutant RAS to Fully Activate Downstream RAS Effector Pathways}

Although the RAS isoforms are highly similar in terms of sequence and structure, the differences in their developmental requirement and mutation rates between cancer types indicate that they are not biologically equivalent. RAS isoforms have differing abilities to activate their downstream effectors $[83,84]$ which are not correlated with a difference in binding affinity [85] or isoform stability [86]. Specifically, HRAS, NRAS, and KRAS show inverse abilities to activate PI3K/AKT signaling and RAF/MEK/ERK signaling: mutant HRAS is a potent activator of PI3K but a relatively poor activator of RAF; conversely, KRAS potently activates RAF but poorly activates PI3K [78,83,84], and NRAS shows intermediate activation of both RAF and PI3K effector pathways (Figure 1C). A recent study has shed light on the mechanism for the differential activation of RAF proteins [87]. Upon RAS activation, RAF proteins form homo- and heterodimers, with BRAF/CRAF heterodimers being the dominant complex responsible for downstream MEK/ERK activation to promote mutant KRAS-driven transformation [88]. BRAF preferentially interacts with KRAS via an interaction between the KRAS (4B) polybasic region and an acidic N-terminal region in BRAF [87]. The ability to directly associate with both BRAF and CRAF makes KRAS a more potent activator of the RAF/MEK/ERK cascade. While the precise mechanism for differential PI3K activation between HRAS and KRAS remains unclear, a major contributor seems to be the polybasic stretch in the hypervariable region (HVR) of KRAS; mutating basic residues in the KRAS (4B) HVR inhibits RAF/MEK/ERK signaling but enhances PI3K/AKT phosphorylation [89]. 
This differential effector activation by RAS isoforms leads to the proposed model that WT RAS contributes to cancer by signaling to effectors that the mutant RAS isoform cannot activate effectively [90]. HRAS-mutated cancer cells require RTK-WT RAS signaling to activate RAF/MEK/ERK signaling [78,91]. Conversely, in KRAS-mutated colorectal [92] and lung [93] adenocarcinoma cells, PI3K/AKT pathway activation is dependent on RTK signaling. Furthermore, we showed that in KRAS-mutated cancer cells, RTK-SOS2-WT RAS signaling was necessary to provide adequate PI3K/AKT signaling for cells to survive in anchorage-independent growth conditions (protection from anoikis) [81], but HRAS- and NRAS-mutated cancer cells could survive in anchorage-independent conditions without RTK-SOS2 supplemented PI3K signaling [82]. These different requirements for WT RAS isoforms in RAS-mutated cancers are also reflected in mutational activation of RAS and downstream RAS effectors. Analysis of co-mutation frequencies shows that $K R A S$ and $B R A F$ mutations are generally mutually exclusive, while KRAS and PIK3CA (the gene encoding the catalytic p $110 \alpha$ subunit of PI3K) mutations co-occur frequently, consistent with the idea that KRAS already highly activates the RAF pathway, but requires supplemental signaling in the PI3K/AKT pathway [94,95]. Thus, WT RAS proteins may contribute to RAS effector activation in RAS-mutated cancer cells through their ability to activate the pathway(s) that the mutant RAS does not activate well (Figure 1).

\section{WT RAS Signaling Underlies Resistance to Targeted Therapies in RAS-Mutated Cancers}

\subsection{Inhibitors of RAS Effector Pathways}

Initial efforts to target $R A S$-mutated cancers focused on inhibiting downstream RAF/MEK/ERK and PI3K/AKT effector signaling, as RAS proteins have been historically difficult to target. Unfortunately, in multiple preclinical models of mutant RAS driven malignancies, single-agent MEK inhibitor treatment is ineffective. In KRAS-mutated cancer cells, single agent MEK inhibitor treatment is ineffective because it both relieves ERK-dependent negative feedback signaling and induces the expression of RTK and ligands [96-105]. These effects cause rapid RTK-WT RAS-dependent activation of both parallel PI3K/AKT signaling and the inhibited RAF/MEK/ERK cascade to drive therapeutic resistance. Similar rebound signaling occurs after MEK inhibitor treatment in HRASand NRAS-mutated cancer cells.

Similar to what is seen after single-agent MEK inhibitor treatment, rebound RTK signaling occurs after PI3K inhibition, with both RAF/MEK/ERK and PI3K/AKT rebound activation [106-108]. Combinations of MEK and PI3K/mTOR inhibitors were successful preclinically [98,109], but clinical success has been limited by toxicity $[108,110,111]$. Unfortunately, toxicity is likely unavoidable with this treatment strategy, since the RAF/MEK/ERK and PI3K/AKT pathways are both key players in normal cell function. To avoid this toxicity, many studies have investigated the efficacy of blocking the PI3K pathway indirectly, or finding other pathways that synergize with MEK or PI3K inhibition [92,112]. In KRAS-mutated colorectal [92] and lung [93] adenocarcinoma cells, PI3K/AKT pathway activation is dependent on RTK-WT RAS signaling (see Section 3.3), and thus inhibition of RTK signaling should indirectly inhibit PI3K activation. For example, Ebi et al. [92] showed that PI3K signaling was most often downstream of IGF-1R in KRAS-mutated colorectal cancer cells and that IGF-1R inhibition did indirectly block PI3K signaling and cooperate with MEK inhibitors to induce cell death.

Unfortunately, it is often difficult to identify which RTK must be co-inhibited with either MEK or PI3K inhibitors for a given tumor type. RNA-sequencing studies showed that MEK inhibitor treatment induces simultaneous upregulation of multiple RTKs and ligands $[113,114]$, so co-inhibition of individual RTKs will likely be ineffective in blocking MEK inhibitor resistance $[97,104,115]$. Further, even specific experiments where a dominant RTK drove MEK inhibitor resistance, the specific RTK involved was either tumor type or more often cell line specific. IGF-IR, MET, ERBB1/2, ERBB3, PDGFRa, AXL and FGFR1 have all been implicated in MEK-inhibitor resistance in KRAS-mutated tumors depending on the anatomical tumor type or specific cell line that was examined [92,97,104,105] (Figure 3). 
These studies indicate that broad inhibition of proximal RTK signaling will likely be required to block MEK inhibitor resistance.

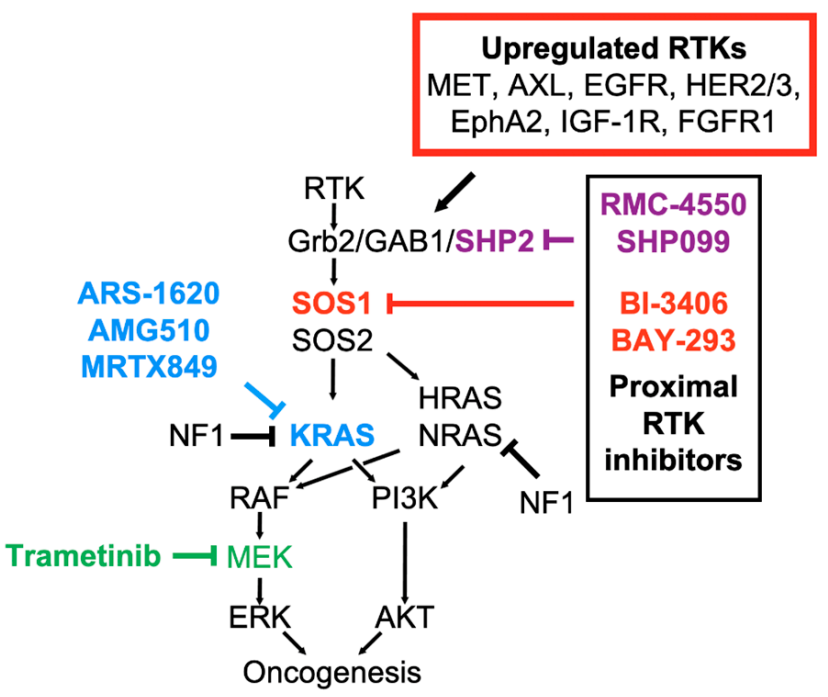

Figure 3. In KRAS-mutated cancer cells, treatment with either KRAS ${ }^{\mathrm{G} 12 \mathrm{C}}$ inhibitors or MEK inhibitors causes rebound RTK signaling leading to therapeutic resistance. Inhibition of proximal RTK signaling using inhibitors of the common proximal RTK signaling intermediates SHP2 or SOS1 can potentially limit resistance to oncogene-targeted therapies, thereby significantly prolonging the initial window of therapeutic efficacy.

\subsection{Mutant RAS Inhibition}

While most early efforts to target RAS have been unsuccessful, recent breakthroughs in both our understanding of an older 'unsuccessful' RAS inhibitor and novel insights into the accessibility of specific RAS mutations have led to renewed hope for successful targeting of mutant RAS in the clinic.

\subsubsection{Tipifarnib as an HRAS-Specific Inhibitor}

For mutant HRAS, advances in our understanding of the enzymes responsible for post-translational lipid modification of RAS isoforms have showed that farnesyltransferase inhibitors (FTIs), drugs originally designed as pan-RAS inhibitors, specifically inhibit HRAS and have clinical activity for patients with HRAS-mutated tumors. All RAS isoforms are post-translationally modified by the covalent addition of a C15 farnesyl isoprenoid lipid at their C-terminus and this modification is required for their membrane association and biological activity. This process, known as prenylation, is normally catalyzed by the enzyme farnesyltransferase (FTase). Since prenylation is required for RAS biological activity, FTIs were developed and tested as therapeutics in RAS-mutated cancers [12]. Unfortunately, KRAS and NRAS, the major RAS isoforms that are mutated in adult cancers, can be alternatively prenylated by gerangeranyltransferases [116-118], and FTIs failed in Phase III clinical trials for KRAS-mutated colorectal [119] and pancreatic [120] cancers. In contrast, HRAS is exclusively farnesylated [121] and its membrane association is inhibited by the FTI tipifarnib. In Phase II trials, patients with HRAS-mutated head and neck squamous cell carcinoma [122], urothelial carcinoma [123], and salivary gland cancer [124] have shown encouraging clinical responses to tipifarnib. Similar to MEK inhibitors (above) and KRAS ${ }^{\mathrm{G} 12 \mathrm{C}}$ inhibitors (below), tipifarnib treatment of HRAS-mutated cancer cells show adaptive reactivation RTK-WT RAS signaling and enhanced RAF/MEK/ERK pathway activation [91]. Furthermore, rebound RTK signaling after tipifarnib treatment occurred through multiple different RTKs in vivo [91], suggesting the need for novel therapeutic combinations. 


\subsubsection{Covalent KRAS ${ }^{\mathrm{G} 12 \mathrm{C}}$ Inhibitors}

Unlike other mutant KRAS proteins, the active -SH group on the cysteine of G12Cmutant KRAS allows for covalent modification using therapeutics. The Shokat lab combined this idea with their discovery of a novel binding pocket on KRAS that is only present in the GDP (inactive) state to develop the first KRAS ${ }^{\text {G12C }}$ inhibitor that binds KRAS in the GDP-bound (inactive) state and covalently modifies the mutant cysteine in KRAS ${ }^{\mathrm{G} 12 \mathrm{C}}$ [15]. Since this first report, there has been a flurry of novel compounds including the bioavailable tool compound ARS-1620 [16] and several clinical compounds, including AMG 510 [17] and MRTX849 [18], both of which are currently in clinical trials for KRAS ${ }^{G 12 C}$-mutated solid tumors. Preliminary reports of patient responses to these drugs are encouraging: $\sim 50 \%$ of patients with KRAS ${ }^{G 12 C}$-mutated NSCLC show partial responses to either AMG 510 or MRTX849, and a majority of the remaining patients show disease stabilization [17,18]. Similar to both FTIs and MEK inhibitors, rapid resistance to KRAS ${ }^{\mathrm{G} 12 \mathrm{C}}$ inhibitors develops. In vitro and in vivo studies revealed upregulated RTK signaling $[18,114,125,126]$ and potential synthesis of new uninhibited KRAS ${ }^{\mathrm{G} 12 \mathrm{C}}$ [126] as the major drivers of KRAS ${ }^{\mathrm{G} 12 \mathrm{C}}$ inhibitor resistance. Similar to MEK inhibitors, the specific RTK driving KRAS ${ }^{\mathrm{G} 12 \mathrm{C}}$ inhibitor resistance is cell type specific, so that while individual RTK inhibitors might be effective in blocking KRAS ${ }^{\mathrm{G} 12 \mathrm{C}}$-inhibitor resistance in a specific cancer cell line, broad inhibition of RTK signaling will be required to delay therapeutic resistance and make KRAS ${ }^{\mathrm{G} 12 \mathrm{C}}$ inhibitors clinically efficacious [18,125-127].

\subsection{Inhibition of Proximal RTK Signaling Can Overcome MEK- and KRAS ${ }^{G 12 C}$-Inhibitor Resistance}

Unbiased genetic and pharmacologic screens revealed three distinct classes of synthetic lethal targets that synergize with both MEK and KRAS ${ }^{\mathrm{G} 12 \mathrm{C}}$ inhibitors in KRASmutated cancer cells [112,127,128]: (i) individual RTKs or proximal RTK signaling components (including SHP2 and SOS1) whose inhibition can broadly inhibit RTK signaling, (ii) mTOR/PI3K survival signaling components, and (iii) regulators of cell cycle progression. Both mTOR/PI3K pathway inhibitors $[128,129]$ and CDK4/ 6 inhibitors $[127,130]$ potentiate the effects of MEK inhibitors and KRAS ${ }^{\mathrm{G} 12 \mathrm{C}}$ inhibitors in xenograft studies, suggesting that targeting these collateral dependencies may be a viable therapeutic strategy. Since PI3K activation is downstream of RTK-WT RAS signaling in KRAS-mutated cancer cells [92,93] and cell cycle progression requires RTK/RAS signaling, these collateral dependent targets may represent a common mechanism for inhibiting MEK- and KRAS ${ }^{\mathrm{G} 12 \mathrm{C}}$-inhibitor resistance [127]. Here, the discovery of potent, orally available SHP2 and SOS1 inhibitors has the potential to dramatically augment oncogene-targeted therapies for $R A S$-mutated cancer.

\subsection{SOS1 and SHP2 Are Therapeutic Targets in RAS-Mutated Cancer Cells}

SHP2 and SOS1 are common proximal RTK signaling intermediates; the development of potent, specific inhibitors for both SHP2 (SHP099 [131,132]; RMC-4550 [133]) and SOS1 (BAY-293 [134]; BI-3406 [135,136]) has led to new approaches to treating RAS-mutated cancers. Both SHP2 [131-133] and SOS1 [134-136] inhibitors are effective in inhibiting cell growth in situ as single agents in cells with RTK/RAS pathway mutations that are dependent upon RAS nucleotide cycling, including cells with EGFR mutations, KRAS (G12/13) mutations, LOF NF1 mutations, and BRAF type III mutations, but not in cells with KRAS Q61 mutations, BRAF Type I/II mutations, or concomitant PIK3CA mutations. In xenograft studies using adult lung, pancreas, or colon cancer cell lines, SHP2 inhibitors enhanced the efficacy of covalent KRAS ${ }^{\mathrm{G} 12 \mathrm{C}}$ inhibitors $[18,114]$ and both SHP2 $[113,137]$ and SOS1 [135] inhibitors enhanced the efficacy of MEK inhibitors. Intriguingly, although neither SHP2 nor SOS1 inhibitors were able to inhibit cancer cells with KRAS Q61 mutations as single agents $[133,135]$, both were able to enhance the efficacy of the MEK inhibitor trametinib in xenograft models harboring KRAS Q61 mutations [113,135], suggesting that inhibiting proximal RTK signaling might be broadly effective in combination therapies for $R A S$-mutated tumors harboring G12, G13, or Q61 mutations. In HRAS- or NRAS-mutated 
cells, neither SHP2 or SOS1 inhibitors are effective as single agents [133,135,138], however, a recent study showed that while $N R A S^{Q 61}$-mutated neuroblastoma cells were insensitive to SHP2 inhibitors alone, combined SHP2 and MEK inhibition showed synergistic inhibition of cell growth [138], suggesting that proximal RTK (SHP2 or SOS1) inhibitors may be a general therapeutic option to overcome MEK inhibitor resistance in RAS-mutated cancer cells.

\subsection{The Spectrum of KRAS Mutations between Different Cancer Types Leads to Cancer-Specific} Vulnerabilities to WT RAS Inhibition

KRAS is the most frequently mutated RAS gene; KRAS mutations occur in $32-35 \%$ of lung adenocarcinomas (LUAD), $41-50 \%$ of colorectal adenocarcinomas (COAD), and $86-88 \%$ of pancreatic adenocarcinomas (PAAD) [3,8]. While G12 mutations predominate each of these cancers, there are cancer-specific differences in the KRAS mutational spectrum that have functional consequences for therapeutics targeting WT RAS signaling [8].

In LUAD, $40 \%$ of $K R A S$ mutations are G12C, whereas KRAS ${ }^{\mathrm{G} 12 C}$ mutations occur less frequently in $\operatorname{COAD}(7 \%)$ and PAAD $(1 \%)[8,11,14]$. Due to these mutational differences, covalent G12C inhibitors (see Section 4.2.2) will likely have the greatest impact in LUAD, where $~ 50 \%$ of patients have shown partial responses in Phase I and II trials $[17,18]$. Similar to MEK inhibition, treatment with covalent KRAS ${ }^{\mathrm{G} 12 \mathrm{C}}$ inhibitors causes rapid rebound activation of multiple RTKs, making RTK-SOS1/2-WT RAS signaling an important therapeutic target in $K R A S^{G 12 C}$-mutated LUAD.

In late-stage colorectal adenocarcinoma, the monoclonal antibodies cetuximab and panitumumab, which inhibit the EGFR, improved outcomes for patients with WT KRAS but not with KRAS mutations [139-143]; these anti-EGFR therapies are FDA approved for first-line treatment for patients with WT KRAS colorectal cancers where they used in combination with conventional chemotherapy [144]. Intriguingly, retrospective analysis of the Phase III trial data assessing the efficacy of cetuximab in COAD showed that patients with $K R A S^{G 13 D}$ mutations may benefit from anti-EGFR therapies [145], although subsequent Phase II trials that prospectively assessed anti-EGFR therapies in patients with $K R A S^{G 13 D}$ mutations have shown varying results [146-148]. COADs have a high percentage of $K R A S^{G 13 D}$ mutations (17\%) compared to either LUAD (3\%) or PAAD (<1\%) [8]. A recent manuscript by $\mathrm{McF}$ all et al. [149] has shed light on why colorectal cancers with $K R A S^{G 13 D}$ mutations might be sensitive to anti-EGFR therapies. In cells with KRAS G13D mutations, WT RAS activation is particularly sensitive to EGFR inhibition [149]. KRAS G12 mutant proteins interact strongly with the RasGAP NF1 and this strong interaction competitively inhibits NF1, activating wild-type HRAS and NRAS independent of EGFR. In contrast, mutant KRASG13D proteins have a relatively weak interaction with NF1, allowing NF1 to inactivate wild-type HRAS and NRAS in the absence of EGFR stimulation and making WT RAS signaling EGFR-dependent in these cells [149]. Due to this, downstream signaling in G13D-mutated cells is extremely RTK-dependent, possibly explaining why $K R A S^{G 13 D}$-mutated colorectal cancers are sensitive to EGFR-TKIs while other KRASmutated colorectal tumors are refractory to EGFR-TKI treatment [145]. Rabara et al. [150] confirmed these results and further showed that a subset of $K R A S^{G 13 D}$-mutated colorectal adenocarcinomas had co-mutation of NF1. Only KRAS ${ }^{G 13 D}$-mutated cancers with WT NF1 were responsive to EGFR inhibition.

In PAAD, $17 \%$ of $K R A S$ mutations are G12R, whereas $K R A S^{G 12 R}$ mutations only occur in $\sim 1 \%$ of COAD and LUAD [8]. Hobbs et al. [151] found that KRAS G12R-mutated PAAD cells have unique signaling properties that may make them vulnerable to WT RAS inhibition. Pancreatic cancer cells are dependent on RAS-driven macropinocytosis for nutrient uptake and survival [152,153]. Using a panel of KRAS-mutated PAAD cell lines, Hobbs et al. [150] showed that while macropinocytosis was KRAS-dependent in KRASG12D and $K R A S^{G 12 V}$-mutated cells, macropinocytosis was KRAS-independent in cells with $K R A S^{G 12 R}$ mutations. They found that compared to cells with G12D or G12V mutations, $K R A S^{G 12 R}$-mutated cells showed defective PI3K-AKT signaling, due to the inability of KRAS $^{\mathrm{G} 12 \mathrm{R}}$ to interact with the p110 $\alpha$ catalytic subunit of PI3K. Macropinocytosis was PI3K $\gamma$-dependent in $K R A S^{G 12 R}$-mutated cells, suggesting that WT RAS signaling was 
specifically required for nutrient uptake in these cells. Due to these unique signaling properties, $K R A S^{G 12 R}$-mutated cells were more sensitive to single-agent PI3K or MEK inhibition compared with $K R A S^{G 12 D}$ and $K R A S^{G 12 V}$-mutated cells [151]. In addition to its inability to interact with $\mathrm{p} 110 \alpha, \mathrm{KRAS}^{\mathrm{G} 12 \mathrm{R}}$ cannot interact with the catalytic domain of SOS1 [151], and isogenic NCI-H23 cells expressing KRAS ${ }^{\mathrm{G} 12 \mathrm{R}}$ were insensitive to SOS1 inhibition [135].

To investigate these findings in a controlled model, Zafra et al. [154] recently generated an in vivo Kras allelic series where they directly compared tumorigenesis and drug sensitives of $\mathrm{Kras}^{\mathrm{G12C}}$, Kras ${ }^{\mathrm{G12D}}$, Kras ${ }^{\mathrm{G} 12 R}$, and $\mathrm{Kras}^{\mathrm{G13D}}$ mutants. In keeping with clinical observations, G12C and G12D mutations showed overall enhanced tumorigenesis in both the colon and pancreas compared to G12R or G13D mutations. Further, when assessing drug sensitivities in pancreatic organoids, $\mathrm{Kras}^{G 13 D}$-mutated organoids were much more sensitive to EGFR inhibition alone compared with other mutants, and $\mathrm{Kras}^{\mathrm{G} 12 \mathrm{C}}$-mutated organoids were sensitive to combining an EGFR inhibitor with covalent KRASG12C inhibition [154], paralleling the findings described above. Taken together, these data indicate that specific KRAS mutations may be more sensitive to inhibitors of WT RAS signaling, leading to organ-specific vulnerabilities based on mutation frequencies.

\section{Conclusions}

WT RAS signaling is an important modifier of RAS-mutated oncogenesis, and inhibition of WT RAS signaling may be required for effective treatment of $R A S$-mutated cancers. Understanding the mechanisms by which WT RAS is activated is an important step in determining the best ways to limit WT RAS signaling. The ability to pharmacologically manipulate the common proximal signaling intermediates SHP2 and SOS1/2 may lead to optimized therapeutic combinations that can be used to treat $R A S$-mutated cancers.

Supplementary Materials: The following are available online at https:/ /www.mdpi.com/article/10 .3390/genes12050662/s1.

Author Contributions: E.S. and R.L.K. conceptualized the manuscript, analyzed the data, and wrote the manuscript. All authors have read and agreed to the published version of the manuscript.

Funding: This research was funded by the Congressionally Directed Medical Research Program/Lung Cancer Research Program grant number LC180213.

Institutional Review Board Statement: Not applicable.

Informed Consent Statement: Not applicable.

Data Availability Statement: The data presented in this study are available in supplemental Table S1. Data were downloaded from https: / / www.depmap.org/depmap, accessed on 27 April 2021 (DepMap Data) and from [54] (siREN Screen Data).

Acknowledgments: We thank Rachel Bagni (NCI) for discussions regarding siREN screen data and Marielle Yohe (NCI) and for thoughtful discussions while preparing this manuscript.

Conflicts of Interest: The authors declare no conflict of interest. The funders had no role in the design of the study; in the collection, analyses, or interpretation of data; in the writing of the manuscript, or in the decision to publish the results.

\section{References}

1. Lemmon, M.A.; Schlessinger, J. Cell signaling by receptor-tyrosine kinases. Cell 2010, 141, 1117-1134. [CrossRef] [PubMed]

2. Papke, B.; Der, C.J. Drugging ras: Know the enemy. Science 2017, 355, 1158-1163. [CrossRef] [PubMed]

3. Prior, I.A.; Hood, F.E.; Hartley, J.L. The frequency of ras mutations in cancer. Cancer Res. 2020, 80, 2969-2974. [CrossRef]

4. Riely, G.J.; Marks, J.; Pao, W. Kras mutations in non-small cell lung cancer. Proc. Am. Thorac. Soc. 2009, 6, 201-205. [CrossRef] [PubMed]

5. Grady, W.M.; Markowitz, S.D. Genetic and epigenetic alterations in colon cancer. Annu. Rev. Rev. Genom. Hum. Genet. 2002, 3, 101-128. [CrossRef] [PubMed] 
6. Jaffee, E.M.; Hruban, R.H.; Canto, M.; Kern, S.E. Focus on pancreas cancer. Cancer Cell 2002, 2, 25-28. [CrossRef]

7. Jemal, A.; Siegel, R.; Xu, J.; Ward, E. Cancer statistics, 2010. CA: A Cancer Journal for Clinicians. Cancer Stat. 2010, 60, 277-300. [CrossRef]

8. Cook, J.H.; Melloni, G.E.M.; Gulhan, D.C.; Park, P.J.; Haigis, K.M. The origins and genetic interactions of kras mutations are alleleand tissue-specific. Nat. Commun. 2021, 12, 1808. [CrossRef]

9. Pylayeva-Gupta, Y.; Grabocka, E.; Bar-Sagi, D. Ras oncogenes: Weaving a tumorigenic web. Nat. Rev. Rev. Cancer 2011, 11, 761-774. [CrossRef]

10. Knickelbein, K.; Zhang, L. Mutant kras as a critical determinant of the therapeutic response of colorectal cancer. Genes Dis. 2015, 2, 4-12. [CrossRef] [PubMed]

11. Haigis, K.M. Kras alleles: The devil is in the detail. Trends Cancer 2017, 3, 686-697. [CrossRef]

12. Stephen, A.G.; Esposito, D.; Bagni, R.K.; McCormick, F. Dragging ras back in the ring. Cancer Cell 2014, 25, 272-281. [CrossRef] [PubMed]

13. Gerber, D.E.; Gandhi, L.; Costa, D.B. Management and future directions in non-small cell lung cancer with known activating mutations. Am. Soc. Clin. Oncol. Educ. Book 2014, e353-65. [CrossRef] [PubMed]

14. Cox, A.D.; Fesik, S.W.; Kimmelman, A.C.; Luo, J.; Der, C.J. Drugging the undruggable ras: Mission possible? Nat. Rev. Rev. Drug. Discov. 2014, 13, 828-851. [CrossRef]

15. Ostrem, J.M.; Peters, U.; Sos, M.L.; Wells, J.A.; Shokat, K.M. K-ras(g12c) inhibitors allosterically control gtp affinity and effector interactions. Nature 2013, 503, 548-551. [CrossRef]

16. Janes, M.R.; Zhang, J.; Li, L.S.; Hansen, R.; Peters, U.; Guo, X.; Chen, Y.; Babbar, A.; Firdaus, S.J.; Darjania, L.; et al. Targeting kras mutant cancers with a covalent g12c-specific inhibitor. Cell 2018, 172, 578-589.e17. [CrossRef] [PubMed]

17. Canon, J.; Rex, K.; Saiki, A.Y.; Mohr, C.; Cooke, K.; Bagal, D.; Gaida, K.; Holt, T.; Knutson, C.G.; Koppada, N.; et al. The clinical kras(g12c) inhibitor amg 510 drives anti-tumour immunity. Nature 2019, 575, 217-223. [CrossRef]

18. Hallin, J.; Engstrom, L.D.; Hargis, L.; Calinisan, A.; Aranda, R.; Briere, D.M.; Sudhakar, N.; Bowcut, V.; Baer, B.R.; Ballard, J.A.; et al The kras(g12c) inhibitor mrtx849 provides insight toward therapeutic susceptibility of kras-mutant cancers in mouse models and patients. Cancer Discov. 2020, 10, 54-71. [CrossRef]

19. McCormick, F. Progress in targeting ras with small molecule drugs. Biochem. J. 2019, 476, 365-374. [CrossRef]

20. Orgovan, Z.; Keseru, G.M. Small molecule inhibitors of ras proteins with oncogenic mutations. Cancer Metastasis Rev. 2020, 39, 1107-1126. [CrossRef]

21. Zhou, B.; Der, C.J.; Cox, A.D. The role of wild type ras isoforms in cancer. Semin. Cell Dev. Biol. 2016, 58, 60-69. [CrossRef]

22. Spandidos, D.A.; Frame, M.; Wilkie, N.M. Expression of the normal h-ras1 gene can suppress the transformed and tumorigenic phenotypes induced by mutant ras genes. Anticancer Res. 1990, 10, 1543-1554.

23. To, M.D.; Rosario, R.D.; Westcott, P.M.; Banta, K.L.; Balmain, A. Interactions between wild-type and mutant ras genes in lung and skin carcinogenesis. Oncogene 2013, 32, 4028-4033. [CrossRef]

24. Diaz, R.; Ahn, D.; Lopez-Barcons, L.; Malumbres, M.; de Castro, I.P.; Lue, J.; Ferrer-Miralles, N.; Mangues, R.; Tsong, J.; Garcia, R.; et al. The n-ras proto-oncogene can suppress the malignant phenotype in the presence or absence of its oncogene. Cancer Res. 2002, 62, 4514-4518.

25. Wang, J.; Liu, Y.; Li, Z.; Wang, Z.; Tan, L.X.; Ryu, M.J.; Meline, B.; Du, J.; Young, K.H.; Ranheim, E.; et al. Endogenous oncogenic nras mutation initiates hematopoietic malignancies in a dose- and cell type-dependent manner. Blood 2011, 118, 368-379. [CrossRef]

26. Diaz, R.; Lue, J.; Mathews, J.; Yoon, A.; Ahn, D.; Garcia-Espana, A.; Leonardi, P.; Vargas, M.P.; Pellicer, A. Inhibition of ras oncogenic activity by ras protooncogenes. Int. J. Cancer 2005, 113, 241-248. [CrossRef]

27. To, M.D.; Perez-Losada, J.; Mao, J.H.; Hsu, J.; Jacks, T.; Balmain, A. A functional switch from lung cancer resistance to susceptibility at the pas1 locus in kras2la2 mice. Nat. Genet. 2006, 38, 926-930. [CrossRef]

28. Zhang, Z.; Wang, Y.; Vikis, H.G.; Johnson, L.; Liu, G.; Li, J.; Anderson, M.W.; Sills, R.C.; Hong, H.L.; Devereux, T.R.; et al. Wildtype kras2 can inhibit lung carcinogenesis in mice. Nat. Genet. 2001, 29, 25-33. [CrossRef]

29. Ambrogio, C.; Kohler, J.; Zhou, Z.W.; Wang, H.; Paranal, R.; Li, J.; Capelletti, M.; Caffarra, C.; Li, S.; Lv, Q.; et al. Kras dimerization impacts mek inhibitor sensitivity and oncogenic activity of mutant kras. Cell 2018, 172, 857-868.e15. [CrossRef]

30. Bentley, C.; Jurinka, S.S.; Kljavin, N.M.; Vartanian, S.; Ramani, S.R.; Gonzalez, L.C.; Yu, K.; Modrusan, Z.; Du, P.; Bourgon, R.; et al. A requirement for wild-type ras isoforms in mutant kras-driven signalling and transformation. Biochem. J. 2013, 452, 313-320. [CrossRef] [PubMed]

31. Nagase, H.; Mao, J.H.; Balmain, A. Allele-specific hras mutations and genetic alterations at tumor susceptibility loci in skin carcinomas from interspecific hybrid mice. Cancer Res. 2003, 63, 4849-4853. [PubMed]

32. Estep, A.L.; Tidyman, W.E.; Teitell, M.A.; Cotter, P.D.; Rauen, K.A. Hras mutations in costello syndrome: Detection of constitutional activating mutations in codon 12 and 13 and loss of wild-type allele in malignancy. Am. J. Med. Genet. A 2006, 140, 8-16. [CrossRef] [PubMed] 
33. Bremner, R.; Balmain, A. Genetic changes in skin tumor progression: Correlation between presence of a mutant ras gene and loss of heterozygosity on mouse chromosome 7. Cell 1990, 61, 407-417. [CrossRef]

34. Buchmann, A.; Bauer-Hofmann, R.; Mahr, J.; Drinkwater, N.R.; Luz, A.; Schwarz, M. Mutational activation of the c-ha-ras gene in liver tumors of different rodent strains: Correlation with susceptibility to hepatocarcinogenesis. Proc. Natl. Acad. Sci. USA 1991, 88, 911-915. [CrossRef]

35. Helias-Rodzewicz, Z.; Funck-Brentano, E.; Terrones, N.; Beauchet, A.; Zimmermann, U.; Marin, C.; Saiag, P.; Emile, J.F. Variation of mutant allele frequency in nras q61 mutated melanomas. BMC Dermatol. 2017, 17, 9. [CrossRef]

36. Qiu, W.; Sahin, F.; Iacobuzio-Donahue, C.A.; Garcia-Carracedo, D.; Wang, W.M.; Kuo, C.Y.; Chen, D.; Arking, D.E.; Lowy, A.M.; Hruban, R.H.; et al. Disruption of p16 and activation of kras in pancreas increase ductal adenocarcinoma formation and metastasis in vivo. Oncotarget 2011, 2, 862-873. [CrossRef]

37. Yu, C.C.; Qiu, W.; Juang, C.S.; Mansukhani, M.M.; Halmos, B.; Su, G.H. Mutant allele specific imbalance in oncogenes with copy number alterations: Occurrence, mechanisms, and potential clinical implications. Cancer Lett. 2017, 384, 86-93. [CrossRef]

38. Li, J.; Zhang, Z.; Dai, Z.; Plass, C.; Morrison, C.; Wang, Y.; Wiest, J.S.; Anderson, M.W.; You, M. Loh of chromosome 12p correlates with kras2 mutation in non-small cell lung cancer. Oncogene 2003, 22, 1243-1246. [CrossRef]

39. Guerrero, I.; Villasante, A.; Corces, V.; Pellicer, A. Loss of the normal n-ras allele in a mouse thymic lymphoma induced by a chemical carcinogen. Proc. Natl. Acad. Sci. USA 1985, 82, 7810-7814. [CrossRef]

40. Soh, J.; Okumura, N.; Lockwood, W.W.; Yamamoto, H.; Shigematsu, H.; Zhang, W.; Chari, R.; Shames, D.S.; Tang, X.; MacAulay, C.; et al. Oncogene mutations, copy number gains and mutant allele specific imbalance (masi) frequently occur together in tumor cells. PLoS ONE 2009, 4, e7464. [CrossRef] [PubMed]

41. Burgess, M.R.; Hwang, E.; Mroue, R.; Bielski, C.M.; Wandler, A.M.; Huang, B.J.; Firestone, A.J.; Young, A.; Lacap, J.A.; Crocker, L.; et al. Kras allelic imbalance enhances fitness and modulates map kinase dependence in cancer. Cell 2017, 168, 817-829.e15. [CrossRef]

42. Chiosea, S.I.; Sherer, C.K.; Jelic, T.; Dacic, S. Kras mutant allele-specific imbalance in lung adenocarcinoma. Mod. Pathol. 2011, 24, 1571-1577. [CrossRef]

43. Chen, X.; Makarewicz, J.M.; Knauf, J.A.; Johnson, L.K.; Fagin, J.A. Transformation by hras(g12v) is consistently associated with mutant allele copy gains and is reversed by farnesyl transferase inhibition. Oncogene 2014, 33, 5442-5449. [CrossRef]

44. Bielski, C.M.; Donoghue, M.T.A.; Gadiya, M.; Hanrahan, A.J.; Won, H.H.; Chang, M.T.; Jonsson, P.; Penson, A.V.; Gorelick, A.; Harris, C.; et al. Widespread selection for oncogenic mutant allele imbalance in cancer. Cancer Cell 2018, 34, 852-862.e4. [CrossRef]

45. Mueller, S.; Engleitner, T.; Maresch, R.; Zukowska, M.; Lange, S.; Kaltenbacher, T.; Konukiewitz, B.; Ollinger, R.; Zwiebel, M.; Strong, A.; et al. Evolutionary routes and kras dosage define pancreatic cancer phenotypes. Nature 2018, 554, 62-68. [CrossRef]

46. Muratcioglu, S.; Jang, H.; Gursoy, A.; Keskin, O.; Nussinov, R. Pdedelta binding to ras isoforms provides a route to proper membrane localization. J. Phys. Chem. B 2017, 121, 5917-5927. [CrossRef]

47. Spencer-Smith, R.; Koide, A.; Zhou, Y.; Eguchi, R.R.; Sha, F.; Gajwani, P.; Santana, D.; Gupta, A.; Jacobs, M.; Herrero-Garcia, E.; et al. Inhibition of ras function through targeting an allosteric regulatory site. Nat. Chem. Biol. 2017, 13, 62-68. [CrossRef]

48. Lin, W.C.; Iversen, L.; Tu, H.L.; Rhodes, C.; Christensen, S.M.; Iwig, J.S.; Hansen, S.D.; Huang, W.Y.; Groves, J.T. H-ras forms dimers on membrane surfaces via a protein-protein interface. Proc. Natl. Acad. Sci. USA 2014, 111, 2996-3001. [CrossRef]

49. Guldenhaupt, J.; Rudack, T.; Bachler, P.; Mann, D.; Triola, G.; Waldmann, H.; Kotting, C.; Gerwert, K. N-ras forms dimers at popc membranes. Biophys. J. 2012, 103, 1585-1593. [CrossRef]

50. Young, A.; Lou, D.; McCormick, F. Oncogenic and wild-type ras play divergent roles in the regulation of mitogen-activated protein kinase signaling. Cancer Discov. 2013, 3, 112-123. [CrossRef]

51. Tsherniak, A.; Vazquez, F.; Montgomery, P.G.; Weir, B.A.; Kryukov, G.; Cowley, G.S.; Gill, S.; Harrington, W.F.; Pantel, S.; Krill-Burger, J.M.; et al. Defining a Cancer Dependency Map. Cell 2017, 170, 564-576.e16. [CrossRef]

52. Meyers, R.M.; Bryan, J.G.; McFarland, J.M.; Weir, B.A.; Sizemore, A.E.; Xu, H.; Dharia, N.V.; Montgomery, P.G.; Cowley, G.S.; Pantel, S.; et al. Computational correction of copy number effect improves specificity of CRISPR-Cas9 essentiality screens in cancer cells. Nat. Genet. 2017, 49, 1779-1784. [CrossRef] [PubMed]

53. Dempster, J.M.; Rossen, J.; Kazachkova, M.; Pan, J.; Kugener, G.; Root, D.E.; Tsherniak, A. Extracting biological insights from the project achilles genome-scale crispr screens in cancer cell lines. bioRxiv 2019, 720243.

54. Yuan, T.L.; Amzallag, A.; Bagni, R.; Yi, M.; Afghani, S.; Burgan, W.; Fer, N.; Strathern, L.A.; Powell, K.; Smith, B.; et al. Differential Effector Engagement by Oncogenic KRAS. Cell Rep. 2018, 22, 1889-1902. [CrossRef]

55. Balbin, O.A.; Prensner, J.R.; Sahu, A.; Yocum, A.K.; Shankar, S.; Malik, R.; Fermin, D.; Dhanasekaran, S.M.; Chandler, B.; Thomas, D.G.; et al. Reconstructing targetable pathways in lung cancer by integrating diverse omics data. Nat. Commun. 2013, 4, 1-13. [CrossRef]

56. Singh, A.; Greninger, P.; Rhodes, D.; Koopman, L.; Violette, S.; Bardeesy, N.; Settleman, J. A Gene Expression Signature Associated with "K-Ras Addiction" Reveals Regulators of EMT and Tumor Cell Survival. Cancer Cell 2009, 15, 489-500. [CrossRef]

57. Singh, A.; Sweeney, M.F.; Yu, M.; Burger, A.; Greninger, P.; Benes, C.; Haber, D.A.; Settleman, J. TAK1 Inhibition Promotes Apoptosis in KRAS-Dependent Colon Cancers. Cell 2012, 148, 639-650. [CrossRef] 
58. Scholl, C.; Fröhling, S.; Dunn, I.F.; Schinzel, A.C.; Barbie, D.A.; Kim, S.Y.; Silver, S.J.; Tamayo, P.; Wadlow, R.C.; Ramaswamy, S.; et al. Synthetic Lethal Interaction between Oncogenic KRAS Dependency and STK33 Suppression in Human Cancer Cells. Cell 2009, 137, 821-834. [CrossRef]

59. Lamba, S.; Russo, M.; Sun, C.; Lazzari, L.; Cancelliere, C.; Grernrum, W.; Lieftink, C.; Bernards, R.; Di Nicolantonio, F.; Bardelli, A. RAF Suppression Synergizes with MEK Inhibition in KRAS Mutant Cancer Cells. Cell Rep. 2014, 8, 1475-1483. [CrossRef]

60. Fujita-Sato, S.; Galeas, J.; Truitt, M.; Pitt, C.; Urisman, A.; Bandyopadhyay, S.; Ruggero, D.; McCormick, F. Enhanced MET Translation and Signaling Sustains K-Ras-Driven Proliferation under Anchorage-Independent Growth Conditions. Cancer Res. 2015, 75, 2851-2862. [CrossRef]

61. Rotem, A.; Janzer, A.; Izar, B.; Ji, Z.; Doench, J.G.; Garraway, L.A.; Struhl, K. Alternative to the soft-agar assay that permits high-throughput drug and genetic screens for cellular transformation. Proc. Natl. Acad. Sci. USA 2015, 112, 5708-5713. [CrossRef]

62. Zhang, Z.; Jiang, G.; Yang, F.; Wang, J. Knockdown of mutant K-ras expression by adenovirus-mediated siRNA inhibits the in vitro and in vivo growth of lung cancer cells. Cancer Biol. Ther. 2006, 5, 1481-1486. [CrossRef]

63. McCormick, F. KRAS as a Therapeutic Target. Clin. Cancer Res. 2015, 21, 1797-1801. [CrossRef]

64. Margarit, S.; Sondermann, H.; Hall, B.E.; Nagar, B.; Hoelz, A.; Pirruccello, M.; Bar-Sagi, D.; Kuriyan, J. Structural Evidence for Feedback Activation by Ras.GTP of the Ras-Specific Nucleotide Exchange Factor SOS. Cell 2003, 112, 685-695. [CrossRef]

65. Sondermann, H.; Soisson, S.M.; Boykevisch, S.; Yang, S.-S.; Bar-Sagi, D.; Kuriyan, J. Structural Analysis of Autoinhibition in the Ras Activator Son of Sevenless. Cell 2004, 119, 393-405. [CrossRef]

66. Boykevisch, S.; Zhao, C.; Sondermann, H.; Philippidou, P.; Halegoua, S.; Kuriyan, J.; Bar-Sagi, D. Regulation of Ras Signaling Dynamics by Sos-Mediated Positive Feedback. Curr. Biol. 2006, 16, 2173-2179. [CrossRef]

67. Iversen, L.F.; Tu, H.-L.; Lin, W.-C.; Christensen, S.M.; Abel, S.M.; Iwig, J.S.; Wu, H.-J.; Gureasko, J.M.; Rhodes, C.P.; Petit, R.S.; et al. Ras activation by SOS: Allosteric regulation by altered fluctuation dynamics. Science 2014, 345, 50-54. [CrossRef] [PubMed]

68. Christensen, S.M.; Tu, H.-L.; Jun, J.E.; Alvarez, S.; Triplet, M.G.; Iwig, J.S.; Yadav, K.K.; Bar-Sagi, D.; Roose, J.P.; Groves, J.T. One-way membrane trafficking of SOS in receptor-triggered Ras activation. Nat. Struct. Mol. Biol. 2016, 23, 838-846. [CrossRef]

69. Huang, W.Y.C.; Alvarez, S.; Kondo, Y.; Lee, Y.K.; Chung, J.K.; Lam, H.Y.M.; Biswas, K.H.; Kuriyan, J.; Groves, J.T. A molecular assembly phase transition and kinetic proofreading modulate Ras activation by SOS. Science 2019, 363, 1098-1103. [CrossRef]

70. Tartaglia, M.; Pennacchio, L.A.; Zhao, C.; Yadav, K.K.; Fodale, V.; Sarkozy, A.; Pandit, B.; Oishi, K.; Martinelli, S.; Schackwitz, W.; et al. Gain-of-function SOS1 mutations cause a distinctive form of Noonan syndrome. Nat. Genet. 2006, 39, 75-79. [CrossRef]

71. Umutesi, H.G.; Hoang, H.M.; Johnson, H.E.; Nam, K.; Heo, J. Development of Noonan syndrome by deregulation of allosteric SOS autoactivation. J. Biol. Chem. 2020, 295, 13651-13663. [CrossRef] [PubMed]

72. Prasad, A.; Zikherman, J.; Das, J.; Roose, J.P.; Weiss, A.; Chakraborty, A.K. Origin of the sharp boundary that discriminates positive and negative selection of thymocytes. Proc. Natl. Acad. Sci. USA 2008, 106, 528-533. [CrossRef]

73. Daniels, M.A.; Teixeiro, E.; Gill, J.; Hausmann, B.; Roubaty, D.; Holmberg, K.; Werlen, G.; Holländer, G.A.; Gascoigne, N.R.J.; Palmer, E. Thymic selection threshold defined by compartmentalization of Ras/MAPK signalling. Nat. Cell Biol. 2006, 444, 724-729. [CrossRef] [PubMed]

74. Kortum, R.L.; Sommers, C.L.; Pinski, J.M.; Alexander, C.P.; Merrill, R.K.; Li, W.; Love, P.E.; Samelson, L.E. Deconstructing Ras Signaling in the Thymus. Mol. Cell. Biol. 2012, 32, 2748-2759. [CrossRef]

75. Roose, J.P.; Mollenauer, M.; Ho, M.; Kurosaki, T.; Weiss, A. Unusual Interplay of Two Types of Ras Activators, RasGRP and SOS, Establishes Sensitive and Robust Ras Activation in Lymphocytes. Mol. Cell. Biol. 2007, 27, 2732-2745. [CrossRef]

76. Das, J.; Ho, M.; Zikherman, J.; Govern, C.; Yang, M.; Weiss, A.; Chakraborty, A.K.; Roose, J.P. Digital Signaling and Hysteresis Characterize Ras Activation in Lymphoid Cells. Cell 2009, 136, 337-351. [CrossRef]

77. Jeng, H.-H.; Taylor, L.J.; Bar-Sagi, D. Sos-mediated cross-activation of wild-type Ras by oncogenic Ras is essential for tumorigenesis. Nat. Commun. 2012, 3, 1-8. [CrossRef]

78. Hamilton, M.; Wolfman, A. Oncogenic Ha-Ras-dependent Mitogen-activated Protein Kinase Activity Requires Signaling through the Epidermal Growth Factor Receptor. J. Biol. Chem. 1998, 273, 28155-28162. [CrossRef]

79. Grabocka, E.; Pylayeva-Gupta, Y.; Jones, M.J.; Lubkov, V.; Yemanaberhan, E.; Taylor, L.; Jeng, H.H.; Bar-Sagi, D. Wild-type H- and N-Ras promote mutant K-Ras-driven tumorigenesis by modulating the DNA damage response. Cancer Cell 2014, 25, 243-256. [CrossRef]

80. Lim, K.-H.; Ancrile, B.B.; Kashatus, D.F.; Counter, C.M. Tumour maintenance is mediated by eNOS. Nat. Cell Biol. 2008, 452, 646-649. [CrossRef]

81. Sheffels, E.; Sealover, N.E.; Wang, C.; Kim, D.H.; Vazirani, I.A.; Lee, E.; Terrell, E.M.; Morrison, D.K.; Luo, J.; Kortum, R.L. Oncogenic RAS isoforms show a hierarchical requirement for the guanine nucleotide exchange factor SOS2 to mediate cell transformation. Sci. Signal. 2018, 11, eaar8371. [CrossRef]

82. Sheffels, E.; Sealover, N.E.; Theard, P.L.; Kortum, R.L. Anchorage-independent growth conditions reveal a differential SOS2 dependence for transformation and survival in RAS-mutant cancer cells. Small GTPases 2021, 12, 67-78. [CrossRef] [PubMed]

83. Yan, J.; Roy, S.; Apolloni, A.; Lane, A.; Hancock, J.F. Ras Isoforms Vary in Their Ability to Activate Raf-1 and Phosphoinositide 3-Kinase. J. Biol. Chem. 1998, 273, 24052-24056. [CrossRef] [PubMed] 
84. Voice, J.K.; Klemke, R.L.; Le, A.; Jackson, J.H. Four Human Ras Homologs Differ in Their Abilities to Activate Raf-1, Induce Transformation, and Stimulate Cell Motility. J. Biol. Chem. 1999, 274, 17164-17170. [CrossRef] [PubMed]

85. Herrmann, C.; Martin, G.A.; Wittinghofer, A. Quantitative Analysis of the Complex between p21 and the Ras-binding Domain of the Human Raf-1 Protein Kinase. J. Biol. Chem. 1995, 270, 2901-2905. [CrossRef]

86. Maher, J.; Baker, D.A.; Manning, M.; Dibb, N.J.; Roberts, I.A. Evidence for cell-specific differences in transformation by N-, H- and K-ras. Oncogene 1995, 11, 1639-1647. [PubMed]

87. Terrell, E.M.; Durrant, D.E.; Ritt, D.A.; Sealover, N.E.; Sheffels, E.; Spencer-Smith, R.; Esposito, D.; Zhou, Y.; Hancock, J.F.; Kortum, R.L.; et al. Distinct Binding Preferences between Ras and Raf Family Members and the Impact on Oncogenic Ras Signaling. Mol. Cell 2019, 76, 872-884.e5. [CrossRef]

88. Freeman, A.K.; Ritt, D.A.; Morrison, D.K. Effects of raf dimerization and its inhibition on normal and disease-associated raf signaling. Mol. Cell 2013, 49, 751-758. [CrossRef]

89. Zhou, Y.; Prakash, P.; Liang, H.; Cho, K.-J.; Gorfe, A.A.; Hancock, J.F. Lipid-Sorting Specificity Encoded in K-Ras Membrane Anchor Regulates Signal Output. Cell 2017, 168, 239-251.e16. [CrossRef]

90. Castellano, E.; Santos, E. Functional Specificity of Ras Isoforms: So Similar but So Different. Genes Cancer 2011, 2, $216-231$. [CrossRef]

91. Untch, B.R.; Dos Anjos, V.; Garcia-Rendueles, M.E.R.; Knauf, J.A.; Krishnamoorthy, G.P.; Saqcena, M.; Bhanot, U.K.; Socci, N.D.; Ho, A.L.; Ghossein, R.; et al. Tipifarnib Inhibits HRAS-Driven Dedifferentiated Thyroid Cancers. Cancer Res. 2018, 78, $4642-4657$. [CrossRef]

92. Ebi, H.; Corcoran, R.B.; Singh, A.; Chen, Z.; Song, Y.; Lifshits, E.; Ryan, D.P.; Meyerhardt, J.A.; Benes, C.; Settleman, J.; et al. Receptor tyrosine kinases exert dominant control over PI3K signaling in human KRAS mutant colorectal cancers. J. Clin. Investig. 2011, 121, 4311-4321. [CrossRef]

93. Molina-Arcas, M.; Hancock, D.C.; Sheridan, C.; Kumar, M.S.; Downward, J. Coordinate Direct Input of Both KRAS and IGF1 Receptor to Activation of PI3 kinase in KRAS-Mutant Lung Cancer. Cancer Discov. 2013, 3, 548-563. [CrossRef]

94. Cerami, E.; Gao, J.; Dogrusoz, U.; Gross, B.E.; Sumer, S.O.; Aksoy, B.A.; Jacobsen, A.; Byrne, C.J.; Heuer, M.L.; Larsson, E.; et al. The cBio Cancer Genomics Portal: An Open Platform for Exploring Multidimensional Cancer Genomics Data. Cancer Discov. 2012, 2, 401-404. [CrossRef]

95. Gao, J.; Aksoy, B.A.; Dogrusoz, U.; Dresdner, G.; Gross, B.; Sumer, S.O.; Sun, Y.; Jacobsen, A.; Sinha, R.; Larsson, E.; et al. Integrative Analysis of Complex Cancer Genomics and Clinical Profiles Using the cBioPortal. Sci. Signal. 2013, 6, pl1. [CrossRef]

96. Turke, A.B.; Song, Y.; Costa, C.; Cook, R.; Arteaga, C.L.; Asara, J.M.; Engelman, J.A. MEK Inhibition Leads to PI3K/AKT Activation by Relieving a Negative Feedback on ERBB Receptors. Cancer Res. 2012, 72, 3228-3237. [CrossRef]

97. Pettazzoni, P.; Viale, A.; Shah, P.; Carugo, A.; Ying, H.; Wang, H.; Genovese, G.; Seth, S.; Minelli, R.; Green, T.; et al. Genetic Events That Limit the Efficacy of MEK and RTK Inhibitor Therapies in a Mouse Model of KRAS-Driven Pancreatic Cancer. Cancer Res. 2015, 75, 1091-1101. [CrossRef] [PubMed]

98. Sos, M.L.; Fischer, S.; Ullrich, R.; Peifer, M.; Heuckmann, J.M.; Koker, M.; Heynck, S.; Stückrath, I.; Weiss, J.; Fischer, F.; et al. Identifying genotype-dependent efficacy of single and combined PI3K- and MAPK-pathway inhibition in cancer. Proc. Natl. Acad. Sci. USA 2009, 106, 18351-18356. [CrossRef] [PubMed]

99. Yohe, M.E.; Gryder, B.E.; Shern, J.F.; Song, Y.K.; Chou, H.-C.; Sindiri, S.; Mendoza, A.; Patidar, R.; Zhang, X.; Guha, R.; et al. MEK inhibition induces MYOG and remodels super-enhancers in RAS-driven rhabdomyosarcoma. Sci. Transl. Med. 2018, 10, eaan4470. [CrossRef] [PubMed]

100. Woodfield, S.E.; Zhang, L.; Scorsone, K.A.; Liu, Y.; Zage, P.E. Binimetinib inhibits MEK and is effective against neuroblastoma tumor cells with low NF1 expression. BMC Cancer 2016, 16, 172. [CrossRef]

101. Jessen, W.J.; Miller, S.J.; Jousma, E.; Wu, J.; Rizvi, T.A.; Brundage, M.E.; Eaves, D.; Widemann, B.; Kim, M.O.; Dombi, E.; et al. Mek inhibition exhibits efficacy in human and mouse neurofibromatosis tumors. J. Clin. Investig. 2013, 123, 340-347. [CrossRef] [PubMed]

102. Hymowitz, S.G.; Malek, S. Targeting the mapk pathway in ras mutant cancers. Cold Spring Harb. Perspect. Med. 2018, 8. [CrossRef] [PubMed]

103. Ryan, M.B.; Corcoran, R.B. Therapeutic strategies to target ras-mutant cancers. Nat. Rev. Rev. Clin. Oncol. 2018, 15, 709-720. [CrossRef] [PubMed]

104. Sun, C.; Hobor, S.; Bertotti, A.; Zecchin, D.; Huang, S.; Galimi, F.; Cottino, F.; Prahallad, A.; Grernrum, W.; Tzani, A.; et al. Intrinsic resistance to mek inhibition in kras mutant lung and colon cancer through transcriptional induction of erbb3. Cell Rep. 2014, 7, 86-93. [CrossRef] [PubMed]

105. Manchado, E.; Weissmueller, S.; Morris, J.P.t.; Chen, C.C.; Wullenkord, R.; Lujambio, A.; de Stanchina, E.; Poirier, J.T.; Gainor, J.F.; Corcoran, R.B.; et al. A combinatorial strategy for treating kras-mutant lung cancer. Nature 2016, 534, 647-651. [CrossRef]

106. Chandarlapaty, S. Negative feedback and adaptive resistance to the targeted therapy of cancer. Cancer Discov. 2012, 2, 311-319. [CrossRef]

107. Chakrabarty, A.; Sanchez, V.; Kuba, M.G.; Rinehart, C.; Arteaga, C.L. Feedback upregulation of her3 (erbb3) expression and activity attenuates antitumor effect of pi3k inhibitors. Proc. Natl. Acad. Sci. USA 2012, 109, 2718-2723. [CrossRef] 
108. Renshaw, J.; Taylor, K.R.; Bishop, R.; Valenti, M.; Brandon, A.d.; Gowan, S.; Eccles, S.A.; Ruddle, R.R.; Johnson, L.D.; Raynaud, F.I.; et al. Dual blockade of the pi3k/akt/mtor (azd8055) and ras/mek/erk (azd6244) pathways synergistically inhibits rhabdomyosarcoma cell growth in vitro and in vivo. Clin. Cancer Res. 2013, 19, 5940-5951. [CrossRef]

109. Engelman, J.A.; Chen, L.; Tan, X.; Crosby, K.; Guimaraes, A.R.; Upadhyay, R.; Maira, M.; McNamara, K.; Perera, S.A.; Song, Y.; et al. Effective use of pi3k and mek inhibitors to treat mutant k-ras g12d and pik3ca h1047r murine lung cancers. Nat. Med. 2008, 14, 1351-1356. [CrossRef]

110. Shimizu, T.; Tolcher, A.W.; Papadopoulos, K.P.; Beeram, M.; Rasco, D.W.; Smith, L.S.; Gunn, S.; Smetzer, L.; Mays, T.A.; Kaiser, B.; et al. The clinical effect of the dual-targeting strategy involving pi3k/akt/mtor and ras/mek/erk pathways in patients with advanced cancer. Clin. Cancer Res. 2012, 18, 2316-2325. [CrossRef]

111. Jokinen, E.; Koivunen, J.P. Mek and pi3k inhibition in solid tumors: Rationale and evidence to date. Ther. Adv. Med. Oncol. 2015, 7, 170-180. [CrossRef]

112. Anderson, G.R.; Winter, P.S.; Lin, K.H.; Nussbaum, D.P.; Cakir, M.; Stein, E.M.; Soderquist, R.S.; Crawford, L.; Leeds, J.C.; Newcomb, R.; et al. A landscape of therapeutic cooperativity in kras mutant cancers reveals principles for controlling tumor evolution. Cell Rep. 2017, 20, 999-1015. [CrossRef] [PubMed]

113. Fedele, C.; Ran, H.; Diskin, B.; Wei, W.; Jen, J.; Geer, M.J.; Araki, K.; Ozerdem, U.; Simeone, D.M.; Miller, G.; et al. Shp2 inhibition prevents adaptive resistance to mek inhibitors in multiple cancer models. Cancer Discov. 2018, 8, 1237-1249. [CrossRef]

114. Fedele, C.; Li, S.; Teng, K.W.; Foster, C.J.R.; Peng, D.; Ran, H.; Mita, P.; Geer, M.J.; Hattori, T.; Koide, A.; et al. Shp2 inhibition diminishes krasg12c cycling and promotes tumor microenvironment remodeling. J. Exp. Med. 2021, 218. [CrossRef]

115. Vitiello, M.; Palma, G.; Monaco, M.; Bello, A.M.; Camorani, S.; Francesca, P.; Rea, D.; Barbieri, A.; Chiappetta, G.; Vita, G.; et al. Dual oncogenic/anti-oncogenic role of patz1 in frtl5 rat thyroid cells transformed by the ha-ras(v12) oncogene. Genes 2019, 10, 127. [CrossRef]

116. Rowell, C.A.; Kowalczyk, J.J.; Lewis, M.D.; Garcia, A.M. Direct demonstration of geranylgeranylation and farnesylation of ki-ras in vivo. J. Biol. Chem. 1997, 272, 14093-14097. [CrossRef]

117. James, G.L.; Goldstein, J.L.; Brown, M.S. Polylysine and cvim sequences of k-rasb dictate specificity of prenylation and confer resistance to benzodiazepine peptidomimetic in vitro. J. Biol. Chem. 1995, 270, 6221-6226. [CrossRef]

118. Whyte, D.B.; Kirschmeier, P.; Hockenberry, T.N.; Nunez-Oliva, I.; James, L.; Catino, J.J.; Bishop, W.R.; Pai, J.K. K- and n-ras are geranylgeranylated in cells treated with farnesyl protein transferase inhibitors. J. Biol. Chem. 1997, 272, 14459-14464. [CrossRef]

119. Rao, S.; Cunningham, D.; de Gramont, A.; Scheithauer, W.; Smakal, M.; Humblet, Y.; Kourteva, G.; Iveson, T.; Andre, T.; Dostalova, J.; et al. Phase iii double-blind placebo-controlled study of farnesyl transferase inhibitor r115777 in patients with refractory advanced colorectal cancer. J. Clin. Oncol. 2004, 22, 3950-3957. [CrossRef]

120. Van Cutsem, E.; van de Velde, H.; Karasek, P.; Oettle, H.; Vervenne, W.L.; Szawlowski, A.; Schoffski, P.; Post, S.; Verslype, C.; Neumann, H.; et al. Phase iii trial of gemcitabine plus tipifarnib compared with gemcitabine plus placebo in advanced pancreatic cancer. J. Clin. Oncol. 2004, 22, 1430-1438. [CrossRef]

121. Cox, A.D.; Der, C.J.; Philips, M.R. Targeting ras membrane association: Back to the future for anti-ras drug discovery? Clin. Cancer Res 2015, 21, 1819-1827. [CrossRef] [PubMed]

122. Ho, A.; Chau, N.; Garcia, I.B.; Ferte, C.; Even, C.; Burrows, F.; Kessler, L.; Mishra, V.; Magnuson, K.; Scholz, C.; et al. Preliminary results from a phase 2 trial of tipifarnib in hras-mutant head and neck squamous cell carcinomas. Int. J. Radiat. Oncol. Biol. Phys. 2018, 100, 1367. [CrossRef]

123. Lee, H.W.; Sa, J.K.; Gualberto, A.; Scholz, C.; Sung, H.H.; Jeong, B.C.; Choi, H.Y.; Kwon, G.Y.; Park, S.H. A phase ii trial of tipifarnib for patients with previously treated, metastatic urothelial carcinoma harboring hras mutations. Clin. Cancer Res. 2020, 26, 5113-5119. [CrossRef]

124. Hanna, G.J.; Guenette, J.P.; Chau, N.G.; Sayehli, C.M.; Wilhelm, C.; Metcalf, R.; Wong, D.J.; Brose, M.; Razaq, M.; Perez-Ruiz, E.; et al. Tipifarnib in recurrent, metastatic hras-mutant salivary gland cancer. Cancer 2020, 126, 3972-3981. [CrossRef] [PubMed]

125. Ryan, M.B.; de la Cruz, F.F.; Phat, S.; Myers, D.T.; Wong, E.; Shahzade, H.A.; Hong, C.B.; Corcoran, R.B. Vertical pathway inhibition overcomes adaptive feedback resistance to kras(g12c) inhibition. Clin. Cancer Res. 2020, 26, 1633-1643. [CrossRef] [PubMed]

126. Xue, J.Y.; Zhao, Y.; Aronowitz, J.; Mai, T.T.; Vides, A.; Qeriqi, B.; Kim, D.; Li, C.; de Stanchina, E.; Mazutis, L.; et al. Rapid non-uniform adaptation to conformation-specific kras(g12c) inhibition. Nature 2020, 577, 421-425. [CrossRef]

127. Lou, K.; Steri, V.; Ge, A.Y.; Hwang, Y.C.; Yogodzinski, C.H.; Shkedi, A.R.; Choi, A.L.M.; Mitchell, D.C.; Swaney, D.L.; Hann, B.; et al. Kras(g12c) inhibition produces a driver-limited state revealing collateral dependencies. Sci. Signal 2019, 12. [CrossRef]

128. Misale, S.; Fatherree, J.P.; Cortez, E.; Li, C.; Bilton, S.; Timonina, D.; Myers, D.T.; Lee, D.; Gomez-Caraballo, M.; Greenberg, M.; et al. Kras g12c nsclc models are sensitive to direct targeting of kras in combination with pi3k inhibition. Clin. Cancer Res. 2019, 25, 796-807. [CrossRef]

129. Molina-Arcas, M.; Moore, C.; Rana, S.; van Maldegem, F.; Mugarza, E.; Romero-Clavijo, P.; Herbert, E.; Horswell, S.; Li, L.S.; Janes, M.R.; et al. Development of combination therapies to maximize the impact of kras-g12c inhibitors in lung cancer. Sci. Transl. Med. 2019, 11. [CrossRef] 
130. Puyol, M.; Martin, A.; Dubus, P.; Mulero, F.; Pizcueta, P.; Khan, G.; Guerra, C.; Santamaria, D.; Barbacid, M. A synthetic lethal interaction between k-ras oncogenes and cdk4 unveils a therapeutic strategy for non-small cell lung carcinoma. Cancer Cell 2010, 18, 63-73. [CrossRef]

131. Chen, Y.N.; LaMarche, M.J.; Chan, H.M.; Fekkes, P.; Garcia-Fortanet, J.; Acker, M.G.; Antonakos, B.; Chen, C.H.; Chen, Z.; Cooke, V.G.; et al. Allosteric inhibition of shp2 phosphatase inhibits cancers driven by receptor tyrosine kinases. Nature 2016, 535, 148-152. [CrossRef]

132. Garcia Fortanet, J.; Chen, C.H.; Chen, Y.N.; Chen, Z.; Deng, Z.; Firestone, B.; Fekkes, P.; Fodor, M.; Fortin, P.D.; Fridrich, C.; et al. Allosteric inhibition of shp2: Identification of a potent, selective, and orally efficacious phosphatase inhibitor. J. Med. Chem. 2016, 59, 7773-7782. [CrossRef] [PubMed]

133. Nichols, R.J.; Haderk, F.; Stahlhut, C.; Schulze, C.J.; Hemmati, G.; Wildes, D.; Tzitzilonis, C.; Mordec, K.; Marquez, A.; Romero, J.; et al. Ras nucleotide cycling underlies the shp2 phosphatase dependence of mutant braf-, nf1- and ras-driven cancers. Nat. Cell Biol. 2018, 20, 1064-1073. [CrossRef]

134. Hillig, R.C.; Sautier, B.; Schroeder, J.; Moosmayer, D.; Hilpmann, A.; Stegmann, C.M.; Werbeck, N.D.; Briem, H.; Boemer, U.; Weiske, J.; et al. Discovery of potent sos1 inhibitors that block ras activation via disruption of the ras-sos1 interaction. Proc. Natl. Acad. Sci. USA 2019, 116, 2551-2560. [CrossRef] [PubMed]

135. Hofmann, M.H.; Gmachl, M.; Ramharter, J.; Savarese, F.; Gerlach, D.; Marszalek, J.R.; Sanderson, M.P.; Kessler, D.; Trapani, F.; Arnhof, H.; et al. Bi-3406, a potent and selective sos1::Kras interaction inhibitor, is effective in kras-driven cancers through combined mek inhibition. Cancer Discov. 2020. [CrossRef]

136. Ramharter, J.; Kessler, D.; Ettmayer, P.; Hofmann, M.H.; Gerstberger, T.; Gmachl, M.; Wunberg, T.; Kofink, C.; Sanderson, M.; Arnhof, H.; et al. One atom makes all the difference: Getting a foot in the door between sos1 and kras. J. Med. Chem. 2021. [CrossRef] [PubMed]

137. Ruess, D.A.; Heynen, G.J.; Ciecielski, K.J.; Ai, J.; Berninger, A.; Kabacaoglu, D.; Gorgulu, K.; Dantes, Z.; Wormann, S.M.; Diakopoulos, K.N.; et al. Mutant kras-driven cancers depend on ptpn11/shp2 phosphatase. Nat. Med. 2018, 24, 954-960. [CrossRef] [PubMed]

138. Valencia-Sama, I.; Ladumor, Y.; Kee, L.; Adderley, T.; Christopher, G.; Robinson, C.M.; Kano, Y.; Ohh, M.; Irwin, M.S. Nras status determines sensitivity to shp2 inhibitor combination therapies targeting the ras-mapk pathway in neuroblastoma. Cancer Res. 2020, 80, 3413-3423. [CrossRef]

139. Karapetis, C.S.; Khambata-Ford, S.; Jonker, D.J.; O'Callaghan, C.J.; Tu, D.; Tebbutt, N.C.; Simes, R.J.; Chalchal, H.; Shapiro, J.D.; Robitaille, S.; et al. K-ras mutations and benefit from cetuximab in advanced colorectal cancer. N. Engl. J. Med. 2008, 359, 1757-1765. [CrossRef]

140. Loupakis, F.; Ruzzo, A.; Cremolini, C.; Vincenzi, B.; Salvatore, L.; Santini, D.; Masi, G.; Stasi, I.; Canestrari, E.; Rulli, E.; et al. Kras codon 61,146 and braf mutations predict resistance to cetuximab plus irinotecan in kras codon 12 and 13 wild-type metastatic colorectal cancer. Br. J. Cancer 2009, 101, 715-721. [CrossRef]

141. Douillard, J.Y.; Oliner, K.S.; Siena, S.; Tabernero, J.; Burkes, R.; Barugel, M.; Humblet, Y.; Bodoky, G.; Cunningham, D.; Jassem, J.; et al. Panitumumab-folfox4 treatment and ras mutations in colorectal cancer. N. Engl. J. Med. 2013, 369, 1023-1034. [CrossRef]

142. Pinto, C.; Normanno, N.; Orlandi, A.; Fenizia, F.; Damato, A.; Maiello, E.; Tamburini, E.; di Costanzo, F.; Tonini, G.; Bilancia, D.; et al. Phase iii study with folfiri + cetuximab versus folfiri + cetuximab followed by cetuximab alone in ras and braf wt mcrc. Future Oncol. 2018, 14, 1339-1346. [CrossRef]

143. Peeters, M.; Douillard, J.Y.; van Cutsem, E.; Siena, S.; Zhang, K.; Williams, R.; Wiezorek, J. Mutant kras codon 12 and 13 alleles in patients with metastatic colorectal cancer: Assessment as prognostic and predictive biomarkers of response to panitumumab. J. Clin. Oncol. 2013, 31, 759-765. [CrossRef] [PubMed]

144. Costas-Chavarri, A.; Nandakumar, G.; Temin, S.; Lopes, G.; Cervantes, A.; Correa, M.C.; Engineer, R.; Hamashima, C.; Ho, G.F.; Huitzil, F.D.; et al. Treatment of patients with early-stage colorectal cancer: Asco resource-stratified guideline. J. Glob. Oncol. 2019, 5, 1-19. [CrossRef] [PubMed]

145. De Roock, W.; Jonker, D.J.; di Nicolantonio, F.; Sartore-Bianchi, A.; Tu, D.; Siena, S.; Lamba, S.; Arena, S.; Frattini, M.; Piessevaux, H.; et al. Association of kras p.G13d mutation with outcome in patients with chemotherapy-refractory metastatic colorectal cancer treated with cetuximab. JAMA 2010, 304, 1812-1820. [CrossRef] [PubMed]

146. Segelov, E.; Thavaneswaran, S.; Waring, P.M.; Desai, J.; Robledo, K.P.; Gebski, V.J.; Elez, E.; Nott, L.M.; Karapetis, C.S.; Lunke, S.; et al. Response to cetuximab with or without irinotecan in patients with refractory metastatic colorectal cancer harboring the kras g13d mutation: Australasian gastro-intestinal trials group icecream study. J. Clin. Oncol. 2016, 34, 2258-2264. [CrossRef]

147. Segelov, E.; Waring, P.; Desai, J.; Wilson, K.; Gebski, V.; Thavaneswaran, S.; Elez, E.; Underhill, C.; Pavlakis, N.; Chantrill, L.; et al. Icecream: Randomised phase ii study of cetuximab alone or in combination with irinotecan in patients with metastatic colorectal cancer with either kras, nras, braf and pi3kca wild type, or g13d mutated tumours. BMC Cancer 2016, 16, 339. [CrossRef]

148. Nakamura, M.; Aoyama, T.; Ishibashi, K.; Tsuji, A.; Takinishi, Y.; Shindo, Y.; Sakamoto, J.; Oba, K.; Mishima, H. Randomized phase ii study of cetuximab versus irinotecan and cetuximab in patients with chemo-refractory kras codon g13d metastatic colorectal cancer (g13d-study). Cancer Chemother. Pharmacol. 2017, 79, 29-36. [CrossRef] 
149. McFall, T.; Diedrich, J.K.; Mengistu, M.; Littlechild, S.L.; Paskvan, K.V.; Sisk-Hackworth, L.; Moresco, J.J.; Shaw, A.S.; Stites, E.C. A systems mechanism for kras mutant allele-specific responses to targeted therapy. Sci. Signal. 2019, 12. [CrossRef]

150. Rabara, D.; Tran, H.T.; Dharmaiah, S.; Stephens, R.M.; McCormick, F.; Simanshu, D.K.; Holderfield, M. KRAS G13D sensitivity to neurofibromin-mediated GTP hydolysis. Proc. Natl. Acad. Sci. USA 2019, 116, 22122-22131. [CrossRef]

151. Hobbs, G.A.; Baker, N.M.; Miermont, A.M.; Thurman, R.D.; Pierobon, M.; Tran, T.H.; Anderson, A.O.; Waters, A.M.; Diehl, J.N.; Papke, B.; et al. Atypical kras(g12r) mutant is impaired in pi3k signaling and macropinocytosis in pancreatic cancer. Cancer Discov. 2020, 10, 104-123. [CrossRef]

152. Commisso, C.; Davidson, S.M.; Soydaner-Azeloglu, R.G.; Parker, S.J.; Kamphorst, J.J.; Hackett, S.; Grabocka, E.; Nofal, M.; Drebin, J.A.; Thompson, C.B.; et al. Macropinocytosis of protein is an amino acid supply route in Ras-transformed cells. Nat. Cell Biol. 2013, 497, 633-637. [CrossRef]

153. Kamphorst, J.J.; Nofal, M.; Commisso, C.; Hackett, S.R.; Lu, W.; Grabocka, E.; Heiden, M.G.V.; Miller, G.; Drebin, J.A.; Bar-Sagi, D.; et al. Human Pancreatic Cancer Tumors Are Nutrient Poor and Tumor Cells Actively Scavenge Extracellular Protein. Cancer Res. 2015, 75, 544-553. [CrossRef]

154. Zafra, M.P.; Parsons, M.J.; Kim, J.; Alonso-Curbelo, D.; Goswami, S.; Schatoff, E.M.; Han, T.; Katti, A.; Fernandez, M.T.C.; Wilkinson, J.E.; et al. An In Vivo Kras Allelic Series Reveals Distinct Phenotypes of Common Oncogenic Variants. Cancer Discov. 2020, 10, 1654-1671. [CrossRef] [PubMed] 